\begin{tabular}{|c|c|c|c|c|c|c|}
\hline \multirow{4}{*}{ Impact Factor: } & ISRA (India) & $=3.117$ & SIS (USA) & $=0.912$ & ICV (Poland) & $=6.630$ \\
\hline & ISI (Dubai, UAE & $=0.829$ & РИНЦ (Russia & $=0.156$ & PIF (India) & $=1.940$ \\
\hline & GIF (Australia) & $=0.564$ & ESJI (KZ) & $=8.716$ & IBI (India) & $=4.260$ \\
\hline & JIF & $=1.500$ & SJIF (Morocco & $=5.667$ & OAJI (USA) & $=0.350$ \\
\hline
\end{tabular}

\section{SOI: $\underline{1.1 / \text { TAS }}$ DOI: $10.15863 /$ TAS \\ International Scientific Journal Theoretical \& Applied Science}

\author{
p-ISSN: 2308-4944 (print) e-ISSN: 2409-0085 (online) \\ Year: 2019 Issue: $07 \quad$ Volume: 75
}

Published: 30.07.2019 http://T-Science.org
QR - Issue

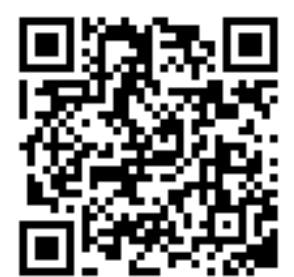

QR - Article

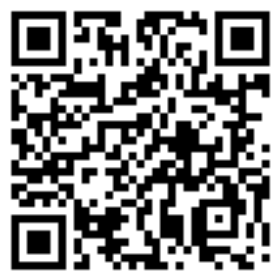

S.M. Anarkulov

National University of Uzbekistan, $\mathrm{PhD}$ researcher, Tashkent, Republic of Uzbekistan nsgi_zr85@mail.ru

\title{
THE ROLE OF SOCIAL INSTITUTES IN SELF-CONSCIOUSNESS OF URBAN POPULATION
}

Abstract: This article explores the role of social institutions (mahalla) in the self-awareness of the urban population. Also, the importance of collective relationships among urban residents is analyzed.

Key words: Central Asia, Tashkent, city, identity, industrial cities, neighborhood, mahalla, tradition, transformation, hashar, wedding, guests.

Language: English

Citation: Anarkulov, S. M. (2019). The role of social institutes in self-consciousness of urban population. ISJ Theoretical \& Applied Science, 07 (75), 390-392.

Soi: http://s-o-i.org/1.1/TAS-07-75-65 Doi: crossef https://dx.doi.org/10.15863/TAS.2019.07.75.65

Classifiers: Geography. History. Oceanology. Meteorology.

\section{Introduction}

Interest in the lives of people living in the world, especially the way of life, traditions and customs of people living in a society to which they did not belong, was started from antiquity. These aspects occupied an important place in determining the essence of people. It is known that there are a number of criteria and standards in determining the identity of each nation. If in certain nations the language is considered an important criterion in establishing a national identity, in others material culture prevails. In some cases, in this aspect, one can observe the predominant role of political self-consciousness. For example, in a population that lives in the USA or in Canada (except for local Indians or some small nations), feelings of commitment to being a citizen of the above-named states or being a taxpayer of a country prevail. It is higher than adherence to some national customs, for example, raising the national flag in front of the house of Americans or Canadians. For the latter, it comes first.

\section{Materials and methods}

If we talk about ethnic groups living in Central Asia, in this aspect it would be appropriate to mention that the Uzbeks have very rich centuries-old traditions. That is why information about the ethnology of the population living in this region is found in a variety of materials relating to ancient history, archaeological monuments, and written sources [1, P.16].

The data studied and analyzed at the present time show that the joint life of various ethnic groups in our country was constantly in the center of attention. Because it is precisely among the Uzbek people that there are peculiar features associated with goodneighborly relations and the large role of "makhalla" in public administration, which are difficult to meet in other countries of the world. After all, the main part of the customs and traditions related to the material culture inherent in the Uzbek people are carried out based on the principles of good neighborly relations. These aspects inherent to the Uzbek people are directly considered in the studies of such scholars as M.I. Filanovich, V.I. Bushkov, S. Abashin, O.A. Sukhareva, S.P. Polyakov and other [2,3,4,5].

It is known that in Soviet times the denial of traditions and customs as remnants of the past was predominant. Despite this, the ideology of the superiority of the public spirit, which is inherent in the Uzbeks, did not lose its basic essence and continued to exist. In the words of the representative of the theory of functionalism, which is widespread in the ethnological science B. Malinovsky, if various customs and traditions are used in certain processes, then they are to some extent necessary for something. 


\begin{tabular}{|c|c|c|c|c|c|c|}
\hline \multirow{4}{*}{ Impact Factor: } & ISRA (India) & $=3.117$ & SIS (USA) & $=0.912$ & ICV (Poland) & $=6.630$ \\
\hline & ISI (Dubai, UAI & $=0.829$ & РИНЦ (Russia & $=0.156$ & PIF (India) & $=1.940$ \\
\hline & GIF (Australia) & $=0.564$ & ESJI (KZ) & $=8.716$ & IBI (India) & $=4.260$ \\
\hline & JIF & $=1.500$ & SJIF (Morocco & $=5.667$ & OAJI (USA) & $=0.350$ \\
\hline
\end{tabular}

Otherwise they would have long gone out of use [6. P. 53-54].

Indeed, the predominance of a common priority and the ideology of the desire to live together, inherent in the peoples of Central Asia, has been formed since antiquity [7. P. 79-80].

In the years of independence, this process has risen to a new level. In particular, in this area, numerous reflections have been noted in the research of ethnological scientists such as Z.Kh. Arifkhanova, G.Sh. Zununova, M.S. Kamaritdinova [8].

Historical processes show that no reality has retained its original appearance. They are constantly for some reason or need, while preserving their essence, subjected to changes in their tasks and forms. People's attitudes toward them have changed. The transformation of good-neighborly relations between the Uzbek peoples, as well as today's attention to such a term as "makhallya", which is social unity, can be attributed to the number of evidence of the abovementioned words.

It is known that since ancient times among our people there are the following wise sayings: "Not a house, but neighbors should be acquired", "Better a neighbor than a relative who lives far away", "If a neighbor is bad, you will get rid of him only after sell the house", they show how important goodneighborly relations are in society. Because, both in grief and in joy, the first to know about your condition are neighbors. Maybe this is why, since antiquity, the Uzbek people have always considered it most necessary to fulfill a duty to a neighbor. If hot bread is baked in the house or any tasty dish is prepared, everyone always shares it with a neighbor. During the construction of residential buildings, the use of the help of neighbors through the organization of "hashar" was a manifestation of good neighborliness.

The study of good neighborly relations between the population of industrial cities show the changes taking place in this area. In particular, this can be clearly seen in the most important problems of material culture, such as the construction of houses, celebrations, and the holding of various events. In this case, the question arises: by what factor do the transformation processes proceed? First of all, the improvement works carried out in the republic, the construction of new and modern residential buildings for the population, as well as the modernization of old ones is the reason for the measures taken in this field.

You can also say about the industrial cities of the Tashkent region. During the years of independence, their appearance has changed radically. According to the Decree of the President of the Republic of Uzbekistan "On the Further Progress of Architecture and Urban Planning of the Republic of Uzbekistan", as well as a result of the resolution $[9,10,11,12]$ on the integrated development of modern cities, large-scale works were carried out.
Today, there is a migration of the population to the industrial cities of the Tashkent region. This in turn will be the cause of population growth. At present, over 150 thousand people live in the town of Chirchik. This, in turn, leads to an increase in the population's need for residential buildings. Taking into account the need of the urban population for residential buildings in the above-mentioned legislative acts and projects, it is planned to build modern and comfortable houses. It is known that modern residential buildings are understood as fully erected residential areas. There will be observed the peculiar features of good neighborly relations, than those that appear in the "makhallas". A variety of festivities, activities related to family life among the urban population will mainly be held in specially built institutions (buildings for weddings, busy mahalla places, etc.). Most of the participants of the events will try to come at a strictly designated time. In some cases, all the means necessary for the host of the event will be provided by home institutions. Whoever holds events will be limited to paying the agreed amount. However, in rural areas or in "makhallas" this process takes place in a peculiar way. According to information, during a wedding or in other events, you can see the active participation of neighbors or members of the "mahalla" in them. In particular, they come long before the start of the event and fulfill their respective duties. In addition, the "hudoi" (an event dedicated to the memory of the deceased) has become a tradition and active participation of women. In addition, funds that are needed in the event (quilt, dishes and others) were also provided through the help of neighbors. In some cases, part of the guests were even settled in the houses of their neighbors. Donations in the cities are carried out by treating men "plov". We can say that in the cities there is no necessary need for assistance from neighbors. In such conditions, in contrast to the rural public, individualist sentiments prevail among the urban population rather than joint or social ones.

In industrial cities, population migration is always high, and the population of cities consists mainly of diverse ethnic groups, ethnographic groups. This in turn was the cause of the manifestation of a kind of ethnocultural processes in the region.

From the first years of independence, special attention has been paid to reviving traditions and restoring customs peculiar to the Uzbek people. Along with them, a number of government decrees were adopted aimed at enhancing the role of "makhallas" in public administration. In particular, the decree "On the Mahalla Committees of Cities, Towns and in Rural Areas of the Republic of Uzbekistan" defines the extension of the duties of the "Mahalla" and its acquisition of official status. Mahalla is an important part of a democratic state.

Now, proceeding from the peculiar properties and duties of the "makhalla", one can observe a 


\begin{tabular}{|c|c|c|c|c|c|c|}
\hline \multirow{4}{*}{ Impact Factor: } & ISRA (India) & $=3.117$ & SIS (USA) & $=0.912$ & ICV (Poland) & $=6.630$ \\
\hline & ISI (Dubai, UAI & $=0.829$ & РИНЦ (Russia & $=0.156$ & PIF (India) & $=1.940$ \\
\hline & GIF (Australia) & $=0.564$ & ESJI (KZ) & $=8.716$ & IBI (India) & $=4.260$ \\
\hline & JIF & $=1.500$ & SJIF (Morocco & $=5.667$ & OAJI (USA) & $=0.350$ \\
\hline
\end{tabular}

bilateral manifestation of its role. The first is the role of "makhallas" as an organizer in events, wedding festivals, in "khashars" in the construction of residential houses and in such processes, which were formed on the basis of old traditions. The leading leader and responsible person of these events is a person from among the active participants in the events, the eldest among the "makhallia" - the aksakalls, or from among those who have vast experience in holding such events and whose word has weight both among the elders and in the circle younger. In this case, the fulfillment of the abovementioned duties on his part is carried out on a voluntary basis, and not on a compulsory one. In addition, this duty is not a constant, everyone can choose another leader for himself. Usually, a person with such responsibilities is chosen from among the most senior close relatives. Even if the scale of his work is very large, his work is not reflected in official documents. Among the people, they can hear the following praise in his address: "he worked hard," "he did the deed of the true head of the family." This kind of "mahalla" has been an integral part of public life for thousands of years.

The role of "makhallas" in the second direction is its direct activity as a state body. In this aspect, the role of "mahalla" is very huge, since, being the most subordinate administrative department and the closest to the people government body, it ensures the implementation of government decrees and adopted laws among the population. In particular, he actively participates in the implementation of state social assistance programs, on support for young people, on issues of educating a harmoniously developed generation, and on tasks to prevent crime and crime. The place and role of the "makhallya" is also indicated separately in the Development Strategy of the Republic of Uzbekistan in five priority areas in the field of building a legal democratic society and further strengthening public oversight among the public.

\section{Conclusion}

The reason for the result, we can say that in recent years there have been a number of changes and transformations in the sphere of activity of such social institutions as "makhallya", as well as in the sphere of good neighborly relations. Surveys show that this social unity has not only retained its value, but also expanded further. It follows from this that the role of public oversight is increasing in public administration. The method of managing society, the process of selfawareness of the Uzbek people and the idea of the superiority of the public spirit, as well as democratic principles, became the main criteria. It is in the full sense of the word "democracy". Samples of which are inherent in the Uzbek people.

\section{References:}

1. Ashirov, A. A. (2007). Ethnology. (p.16). Tashkent: O'zbekiston.

2. Suxareva, O. A. (1978). Kvartalnaya obshina pozdnesrednevekovogo goroda Buxari. Moscow.

3. Bushkov, V. I. (1995). Tadjikistan: traditsionnoye soobshestvo $\mathrm{v}$ postindustrialnom mire. Etnograficheskoye obrazovaniye. №4.

4. Abashin, S. (1999). Vopreki "zdravomu smislu". $\mathrm{K}$ voprosu o ratsionalnosti irratsionalnosti ritualnix rasxodov v Sredney Azii. Vestnik Evreazii. №1-2.

5. Filanovich, M. I. (2003). O nekotorix aspektax istorii obshini $\mathrm{v}$ drevnosti I proisxojdenii "maxalla". O'zbekiston tarixi №2,

6. Sadoxin, A. P. (n.d.). Ethnology. (pp. 53-54). Moscow: Gardariki.

7. Kaykovus (1994). Qobusnoma. (pp. 79-80). Tashkent: Istiqlol.

8. (2005). Sovremenniye etnokulturniye protsessi v maxallyax Tashkenta. Tashkent: Fan.
9. (2000). "On the approval of the regulation on the development of master plans and development of cities, district centers and urbantype settlements". Tashkent, Decision \# 320 of 14.08.2000.

10. (2009). "On additional measures to strengthen control over the strict implementation of townplanning norms and rules in the implementation of integrated development of human settlements". Tashkent, Decision \# 41 of 12.02.2009

11. (2009). "On the approval of the rules for organizing works on the improvement of settlements, taking into account modern architectural and town planning requirements". Tashkent, Decision \# 59 of 09.03.2009.

12. (2017). "On additional measures to regulate the carrying out of town-planning activity in some settlements of the Tashkent region". Tashkent, Decision \# 981 of 12.12.2017. 